\title{
THE RELATION BETWEEN PULMONARY HYPERTENSION MEASURED BY STANDARD TRANSTHORACIC ECHOCARDIOGRAPHY AND T WAVE AND R WAVE ALTERNANS IN ELECTROCARDIOGRAM
}

\author{
Ahmed Hendawy Radwan Ali Radwan, Adham Abdeltawab, \\ Ahmed Mohamed Onsy and Nireen Kh. Okasha
}

\begin{abstract}
Department of Cardiology,

Background: While the exact frequency of pulmonary hypertension Faculty of Medicine, Ain Shams University

Corresponding:

Ahmed Hendawy Radwan

Mobile: 01020657047;

Email:

drahmedhendawy8@gmail.com

Received: 4/8/2020

Accepted: 26/8/2020

Online ISSN: 2735-3540 is unknown, it is estimated that about 1,000 new cases occur a year in the United States. Females are more often affected than males. Onset is typically between 20 and 60 years of age. It was first identified by Ernst von Romberg in 1891.

Aim of the work: To determine the correlation between ECG voltage variability and presence \& severity of pulmonary hypertension.

Patients and Methods: This study was conducted on 80 patients who presented to the outpatient clinic of Ain Shams university hospital and Nasser institute hospital, in the period between May 2019 and March 2020. Patients were divided into 40 patients with pulmonary hypertension (PASP>35 $\mathrm{mm} \mathrm{Hg}$ ) and 40 patients (age and sex matched) with normal pulmonary artery pressure, patients were subjected to full history taking, ECG, laboratory investigations, complete transthoracic Echocardiography.

Results: We found that there was no statistically significant difference between both groups as regards the incidence of $Q T$ dispersion, $T$ wave alternans and QRS alternans. In addition, there was no statistically significant difference between the degree of pulmonary hypertension and incidence of $Q T$ dispersion, $T$ wave alternans and QRS alternans.

Conclusion: In the present study we found that there is no significant relation between $T$ wave alternans, $R$ wave alternans and $Q T$ dispersion as parameters of ECG voltage variability and PAH. In addition, there is no significant relation between the degree of pulmonary hypertension and the degree of $Q T$ dispersion, $T$ wave alternans and QRS alternans.
\end{abstract}

Keywords: pulmonary hypertension $-T$ wave alternans- $R$ wave alternans - QT dispersion.

\section{INTRODUCTION:}

Pulmonary arterial hypertension (PAH) is a progressive disorder with a complex pathology. It initially involves mostly the right ventricle, and eventually to its distension, dysfunction, and symptomatic insufficiency.
PAH exact frequency is unknown, but the yearly new cases are about 1,000 cases in the United States. Females are more often affected than males and typically between 20 and 60 years of age $\mathrm{e}^{(1)}$. 
$\mathrm{PAH}$ has five major types and a careful physical examination in addition to series of tests such as ECG, echocardiography and right heart catheterization must be performed to distinguish pulmonary arterial hypertension from venous, hypoxic, thromboembolic, or unclear multifactorial varieties ${ }^{(2)}$.

However there is modern diseasespecific therapy, patients with $\mathrm{PAH}$ is still characterized by a high overall mortality. Independent mortality risk factors include clinical characteristics (age, World Health Organization functional class, 6-min walk distance, etiology, family history), hemodynamic parameters (left atrial pressure, pulmonary pressure), echocardiography findings (pleural effusion), and laboratory tests (brain natriuretic peptide) ${ }^{(3)}$.

Although sudden cardiac death is a complication for $30 \%-40 \%$ of PAH patients, this issue has not been studied extensively, and neither the mechanisms underlying SCD in this group of patients nor the risk factors have been unequivocally defined ${ }^{(4)}$.

T-wave alternans (TWA) is a wellexamined parameter for the risk stratification of sudden cardiac death (SCD) in patients with left ventricular dysfunction (LVD). However, the role of TWA in pulmonary arterial hypertension (PAH) remains obscure. Consequently, the present study aimed to analyze the profile of TWA among PAH patients in comparison with healthy volunteers ${ }^{(5)}$.

\section{PATIENTS AND METHODS:}

\section{Patients:}

This study was conducted on 40 patients with pulmonary hypertension (PASP $>35$ $\mathrm{mm} \mathrm{Hg}$ ) and 40 patients (age and sex matched) with normal pulmonary artery pressure recruited for Nasser Institute Hospital (NIH) and Ain Shams University Hospitals (ASUH).
Patients were subdivided into two groups according to their pulmonary artery systolic pressure measured by transthoracic ECHO

\section{○ $\operatorname{Group}(A):$}

Patients who have PASP> $35 \mathrm{~mm} \mathrm{Hg}$.

\section{$\circ \operatorname{Group}(B):$}

Patients who have normal PASP.

\section{Inclusion criteria:}

Our study included 40 patients with pulmonary hypertension (PASP $>35 \mathrm{~mm} \mathrm{Hg}$ ) and 40 patients (age and sex matched) with normal pulmonary artery pressure recruited for Nasser Institute Hospital (NIH) and Ain Shams University Hospitals (ASUH).

\section{Exclusion criteria:}

1. Patients with Ejection fraction less than $40 \%$.

2. Patients with Sever stenotic or regurgitant valvular lesions.

3. Patients less than 18 ys or more than 80 ys.

4. Patients have end stage renal disease.

5. Pregnant females.

6. Patient's refusal.

\section{Methods:}

All patients were subjected to:

- Full history taking.

- Full clinical examination.

- 12 lead surface ECG: was done to patient, using normal standardization of $25 \mathrm{~mm} / \mathrm{sec}$ and $10 \mathrm{~mm} / 1 \mathrm{mv}$. ECG analysis and measurements were done later. The following voltage parameters were analyzed:

a. QT dispersion: The QT interval was measured from the beginning of the QRS complex to the end of the $T$ wave. When a $T$ wave was interrupted by the $\mathrm{U}$ wave, the end of the $\mathrm{T}$ wave was 
defined as the nadir between the $\mathrm{T}$ and the $U$ waves. If the end of the $T$ wave could not be reliably determined due to extremely low voltage $(<0.1 \mathrm{mV})$, measurements of the QT interval were not made, and those leads were excluded from the analysis. QT interval was corrected to heart rate and the difference between maximum and minimum corrected QT interval was compared between patients with pulmonary hypertension and individuals with normal PASP (QT dispersion=QTc $\max -\mathrm{QTc} \min )^{(6)}$.

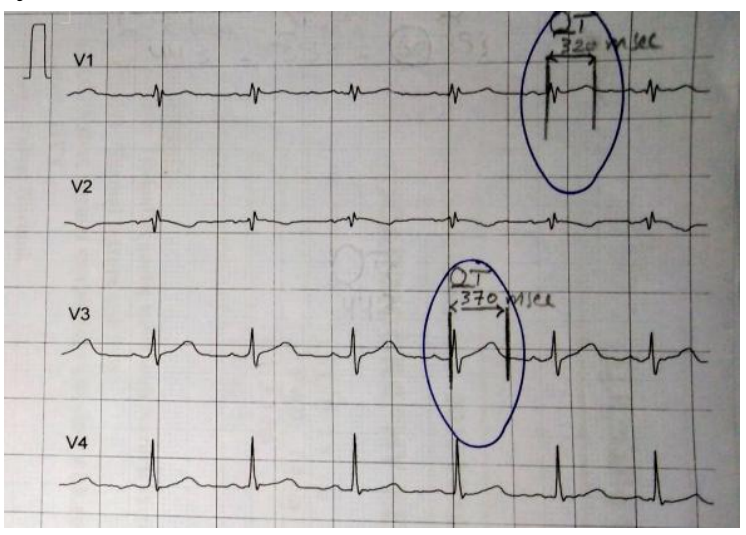

Figure 1: Example of measuring QT dispersion

QT dispersion $=$ QTc $\max -\mathrm{QTc} \min (443-383)=60$

- Note: QT was corrected to the heart rate through Medscape app using Bazett's formula (Bazett's formula: $\mathrm{QT}_{\mathrm{C}}=\mathrm{QT} /$ $\sqrt{ } \mathrm{RR})^{(7)}$.

b. Twave alternans (TWA): defined as change in the amplitude and/or morphology of a component of the ECG that occurs on an every-other-beat basis has been closely linked to electrical instability in the heart. TWA is now established among the strongest markers of susceptibility to sudden cardiac death. Presence of TWA detected by visual observation will be compared in patients with pulmonary hypertension and individuals with normal $\mathrm{PASP}^{(8)}$.

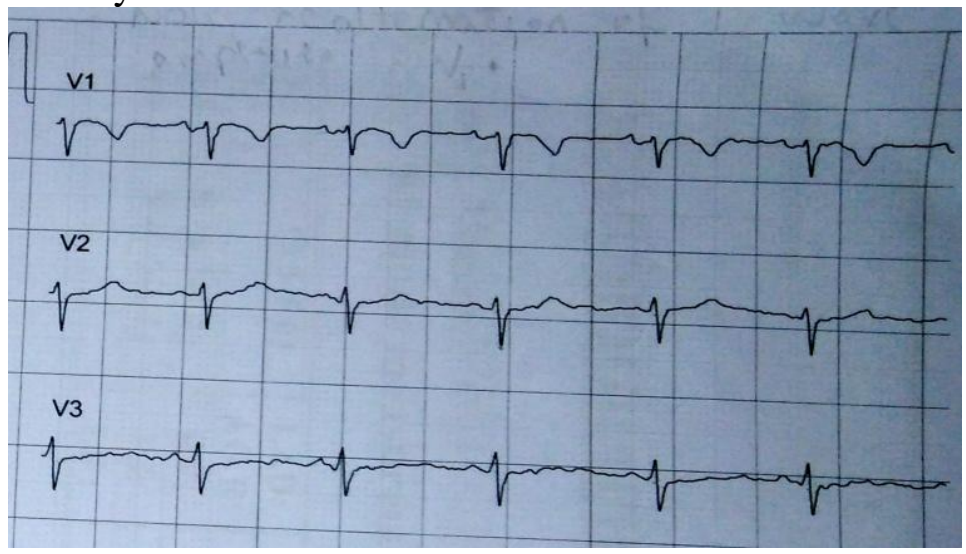

Figure 2: Example of T Wave alternans in amplitude in V1

c. QRS complex alternans: Presence of QRS alternans detected by measurement of QRS width and amplitude in different beats and comparing difference from beat to beat in both controls and study subjects will be compared in patients with pulmonary hypertension and individuals with normal PASP ${ }^{(9)}$. 


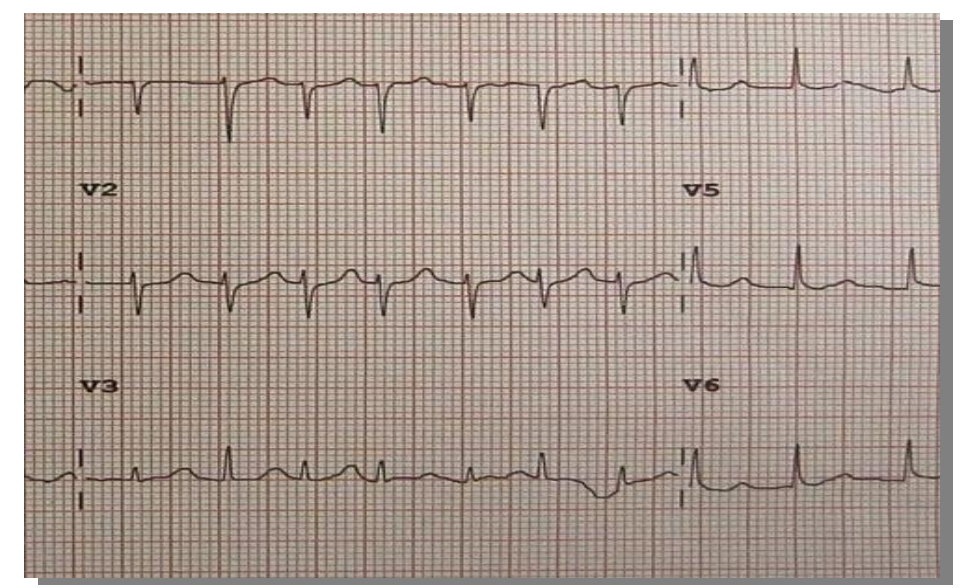

Figure 3: Example of QRS alternans in amplitude in V1-3 standard transthoracic echo.

Transthoracic echocardiographic examination with machine-integrated ECG recording was performed, mostly with the patients lying in the left lateral decubitus position, using Vivid E9 machine with an M4S matrix sector array probe with a frequency of $2.5 \mathrm{Mega} \mathrm{Hz}$ (General Electric Vingmed Ultrasound, Horten, Norway) and the following data were assessed:

- Left side study: LV. Dimensions, EF by Simpson`s method, FS, presence of intracardiac mass, LV diastolic functions ${ }^{(10)}$.

- Right side study: ${ }^{(11)}$

1- RV. Size: Basal, mid and longitudinal.

\section{2- TAPSE.}

3- TR degree from apical 4 chamber view by measuring jet area, vena contracta width, jet density and color, and RV, RA size.

4-Pulmonary artery pressure:

$\mathrm{A}-\mathrm{RVSP}=4(\mathrm{~V}) 2+\mathrm{RA}$ pressure, where $\mathrm{V}$ is the peak velocity (in meters per second) of the tricuspid valve regurgitant jet, and RA pressure is estimated from IVC diameter and respiratory changes.

B- If PR. exists: PADP $=4 \mathrm{x}$ (end-diastolic pulmonary regurgitant velocity) $2+$ RAP.

\section{RESULTS:}

Results are discussed in two sections in which section (1) discussing the statistical analysis between patients with pulmonary hypertension in general and patients with normal PAP, while section (2) discussing the statistical analysis between patients with mild $\mathrm{PAH}$ and patients with moderate to severe PAH.

\section{Section (1)}

Patients were divided into two (2) groups: group A patients with pulmonary hypertension (PASP>35) and group B patients (age and sex matched) with normal pulmonary artery pressure. 
Table (1): Comparison between group A and group B regarding demographic data and risk factors

\begin{tabular}{|c|c|c|c|c|c|c|}
\hline & Group A & Group B & \multirow[t]{2}{*}{ Test value } & \multirow[t]{2}{*}{ P-value } & \multirow[t]{2}{*}{ Sig. } \\
\hline & & No. $=40$ & No. $=40$ & & & \\
\hline \multirow[t]{2}{*}{ Age } & Mean \pm SD & $54.43 \pm 9.11$ years & $50.55 \pm 7.91$ years & \multirow[t]{2}{*}{$2.030^{\bullet}$} & \multirow[t]{2}{*}{0.046} & \multirow[t]{2}{*}{$\mathrm{S}$} \\
\hline & Range & $36-69$ years & $37-67$ years & & & \\
\hline \multirow[t]{2}{*}{ Sex } & Female & $22(55.0 \%)$ & $21(52.5 \%)$ & \multirow[t]{2}{*}{$0.050 *$} & \multirow[t]{2}{*}{0.823} & \multirow[t]{2}{*}{ NS } \\
\hline & Male & $18(45.0 \%)$ & $19(47.5 \%)$ & & & \\
\hline \multirow[t]{2}{*}{ DM } & No & $19(47.5 \%)$ & $25(62.5 \%)$ & \multirow[t]{2}{*}{$1.818^{*}$} & \multirow[t]{2}{*}{0.178} & \multirow[t]{2}{*}{$\mathrm{NS}$} \\
\hline & Yes & $21(52.5 \%)$ & $15(37.5 \%)$ & & & \\
\hline \multirow[t]{2}{*}{ HTN } & No & $18(45.0 \%)$ & $11(27.5 \%)$ & \multirow[t]{2}{*}{$2.650 *$} & \multirow[t]{2}{*}{0.104} & \multirow[t]{2}{*}{ NS } \\
\hline & Yes & $22(55.0 \%)$ & $29(72.5 \%)$ & & & \\
\hline
\end{tabular}

Table (2) comparative data between group A and group B regarding the ECG repolarization parameters

\begin{tabular}{|c|c|c|c|c|c|c|}
\hline & Group A & Group B & \multirow[t]{2}{*}{ Test value } & \multirow[t]{2}{*}{ P-value } & \multirow[t]{2}{*}{ Sig. } \\
\hline & & No. $=40$ & No. $=40$ & & & \\
\hline \multirow[t]{2}{*}{ QT max } & Mean \pm SD & $424.45 \pm 34.21$ & $422.48 \pm 31.52$ & \multirow[t]{2}{*}{$0.269 \bullet$} & \multirow[t]{2}{*}{0.789} & \multirow[t]{2}{*}{ NS } \\
\hline & Range & $345-501 \mathrm{M} \mathrm{Sec}$ & $367-542 \mathrm{M} \mathrm{Sec}$ & & & \\
\hline \multirow[t]{2}{*}{ QT min } & Mean \pm SD & $399.10 \pm 39.75$ & $404.03 \pm 33.92$ & \multirow[t]{2}{*}{$-0.596 \bullet$} & \multirow[t]{2}{*}{0.553} & \multirow[t]{2}{*}{ NS } \\
\hline & Range & $306-485$ M Sec & $336-470 \mathrm{M} \mathrm{Sec}$ & & & \\
\hline \multirow[t]{2}{*}{ QT dispersion } & Mean \pm SD & $33.80 \pm 14.12$ & $33.55 \pm 17.27$ & \multirow[t]{2}{*}{$0.058 \bullet$} & \multirow[t]{2}{*}{0.954} & \multirow[t]{2}{*}{$\mathrm{NS}$} \\
\hline & Range & $10-68 \mathrm{M} \mathrm{Sec}$ & $8-82 \mathrm{M} \mathrm{Sec}$ & & & \\
\hline \multirow{2}{*}{$\begin{array}{l}\text { T wave alternans } \\
\text { amplitude }\end{array}$} & Absent & $33(82.5 \%)$ & $29(72.5 \%)$ & \multirow[t]{2}{*}{$1.147 *$} & \multirow[t]{2}{*}{0.284} & \multirow[t]{2}{*}{ NS } \\
\hline & Present & $7(17.5 \%)$ & $11(27.5 \%)$ & & & \\
\hline \multirow{2}{*}{$\begin{array}{l}\mathrm{T} \text { wave alternans } \\
\text { morphology }\end{array}$} & Absent & $38(95.0 \%)$ & $38(95.0 \%)$ & \multirow[t]{2}{*}{$0.000^{*}$} & \multirow[t]{2}{*}{1.000} & \multirow[t]{2}{*}{ NS } \\
\hline & Present & $2(5.0 \%)$ & $2(5.0 \%)$ & & & \\
\hline \multirow[t]{2}{*}{ QRS alternans } & Absent & $7(17.5 \%)$ & $5(12.5 \%)$ & \multirow[t]{2}{*}{$0.392 *$} & \multirow[t]{2}{*}{0.531} & \multirow[t]{2}{*}{ NS } \\
\hline & Present & $33(82.5 \%)$ & $35(87.5 \%)$ & & & \\
\hline
\end{tabular}

Table (3) Comparison between group A and group B regarding ejection fraction, LV dimensions and diastolic function.

\begin{tabular}{|c|c|c|c|c|c|c|}
\hline & Group A & Group B & \multirow[t]{2}{*}{ Test value } & \multirow[t]{2}{*}{ P-value } & \multirow[t]{2}{*}{ Sig. } \\
\hline & & No. $=40$ & No. $=40$ & & & \\
\hline \multirow[t]{2}{*}{$\mathrm{EF}(\%)$} & Mean \pm SD & $57.55 \pm 11.07$ & $64.48 \pm 6.13$ & \multirow[t]{2}{*}{$-3.462 \bullet$} & \multirow[t]{2}{*}{0.001} & \multirow[t]{2}{*}{$\mathrm{HS}$} \\
\hline & Range & $41-79 \%$ & $50-76 \%$ & & & \\
\hline \multirow[t]{2}{*}{ Dimensions } & Normal & $28(70.0 \%)$ & $40(100.0 \%)$ & \multirow[t]{2}{*}{$14.118 *$} & \multirow[t]{2}{*}{0.000} & \multirow[t]{2}{*}{$\mathrm{HS}$} \\
\hline & Dilated LV & $12(30.0 \%)$ & $0(0.0 \%)$ & & & \\
\hline \multirow[t]{5}{*}{ Diastolic function } & Normal & $20(50.0 \%)$ & $14(35.0 \%)$ & \multirow[t]{5}{*}{$6.559 *$} & \multirow[t]{5}{*}{0.161} & \multirow[t]{5}{*}{ NS } \\
\hline & GI DD & $15(37.5 \%)$ & $25(62.5 \%)$ & & & \\
\hline & GII DD & $3(7.5 \%)$ & $1(2.5 \%)$ & & & \\
\hline & GIII DD & $1(2.5 \%)$ & $0(0.0 \%)$ & & & \\
\hline & MR-TR & $1(2.5 \%)$ & $0(0.0 \%)$ & & & \\
\hline
\end{tabular}


Table (4): Comparison between group A and group B regarding the valvular diseases, fractional shortening, RV size and function.

\begin{tabular}{|c|c|c|c|c|c|c|}
\hline & Group A & Group B & \multirow[t]{2}{*}{ Test value } & \multirow{2}{*}{ P-value } & \multirow[t]{2}{*}{ Sig. } \\
\hline & & No. $=40$ & No. $=40$ & & & \\
\hline \multirow[t]{4}{*}{ Aorta } & Normal & $35(87.5 \%)$ & $34(85.0 \%)$ & \multirow[t]{4}{*}{$1.414^{*}$} & \multirow[t]{4}{*}{0.493} & \multirow[t]{4}{*}{ NS } \\
\hline & Mild AR & $4(10.0 \%)$ & $6(15.0 \%)$ & & & \\
\hline & Moderate AR & $0(0.0 \%)$ & $0(0.0 \%)$ & & & \\
\hline & Sclerosed AV & $1(2.5 \%)$ & $0(0.0 \%)$ & & & \\
\hline \multirow[t]{3}{*}{ Mitral } & Normal & $13(32.5 \%)$ & $31(77.5 \%)$ & \multirow[t]{3}{*}{ 19.364* } & \multirow[t]{3}{*}{0.000} & \multirow[t]{3}{*}{ HS } \\
\hline & Mild MR & $18(45.0 \%)$ & $9(22.5 \%)$ & & & \\
\hline & Moderate MR & $9(22.5 \%)$ & $0(0.0 \%)$ & & & \\
\hline Pulmonary & Normal & $40(100.0 \%)$ & $40(100.0 \%)$ & NA & NA & NA \\
\hline \multirow{3}{*}{ Tricuspid } & Normal & $0(0.0 \%)$ & $19(47.5 \%)$ & \multirow[t]{3}{*}{$28.073^{*}$} & \multirow[t]{3}{*}{0.000} & \multirow[t]{3}{*}{ HS } \\
\hline & Mild TR & $34(85.0 \%)$ & $21(52.5 \%)$ & & & \\
\hline & Moderate TR & $6(15.0 \%)$ & $0(0.0 \%)$ & & & \\
\hline \multirow[t]{2}{*}{ RV size } & Normal & $39(97.5 \%)$ & $40(100.0 \%)$ & \multirow[t]{2}{*}{$1.013 *$} & \multirow[t]{2}{*}{0.314} & \multirow[t]{2}{*}{ NS } \\
\hline & Dilated & $1(2.5 \%)$ & $0(0.0 \%)$ & & & \\
\hline \multirow[t]{2}{*}{ TAPSE } & Mean \pm SD & $17.23 \pm 2.66$ & $17.58 \pm 2.34$ & \multirow[t]{2}{*}{$-0.624 \bullet$} & \multirow[t]{2}{*}{0.534} & \multirow[t]{2}{*}{ NS } \\
\hline & Range & $12-22$ & $13-22$ & & & \\
\hline \multirow[t]{2}{*}{ FS } & Mean \pm SD & $33.10 \pm 10.16$ & $35.20 \pm 4.87$ & \multirow[t]{2}{*}{$-1.178 \bullet$} & \multirow[t]{2}{*}{0.242} & \multirow[t]{2}{*}{ NS } \\
\hline & Range & $20-64 \%$ & $25-45 \%$ & & & \\
\hline
\end{tabular}

Table (5): Univariate logistic regression analysis for PAH in group A

\begin{tabular}{|l|c|c|c|c|c|c|c|}
\hline & B & S.E. & Wald & P-value & \multicolumn{2}{|c|}{ Odds ratio } & \multicolumn{2}{|c|}{ 95\% C.I. for OR } \\
\cline { 6 - 8 } & & & & & (OR) & Lower & Upper \\
\hline Age $>52$ years & 1.136 & 0.467 & 5.920 & 0.015 & 3.115 & 1.247 & 7.781 \\
\hline $\mathrm{EF} \leq 55 \%$ & 2.944 & 0.791 & 13.842 & 0.000 & 19.000 & 4.028 & 89.618 \\
\hline
\end{tabular}

Table (6): Multi-varialte logistic regression analysis for predictors of group A

\begin{tabular}{|l|c|c|c|c|c|c|c|}
\hline & B & S.E. & Wald & P-value & \multicolumn{2}{|c|}{ Odds ratio } & \multicolumn{2}{|c|}{ 95\% C.I. for OR } \\
\cline { 6 - 8 } & & & & & Lower & Upper \\
\hline Age $>52$ years & 1.086 & 0.570 & 3.623 & 0.057 & 2.961 & 0.968 & 9.057 \\
\hline $\mathrm{EF} \leq 55 \%$ & 2.656 & 1.030 & 6.646 & 0.010 & 14.244 & 1.890 & 107.336 \\
\hline
\end{tabular}

\section{Section (2)}

Patients with PAH were subdivided into two subgroups according to the degree of

PAH as follows: Group I: Patients have Mild
PAH (PASP 35-45 mm Hg). Group II:

Patients have Moderate to severe (PASP > $45 \mathrm{mmHg}$ ).

Table (7): The relation between risk factors and demographic data with degree of pulmonary hypertension in group A

\begin{tabular}{|c|c|c|c|c|c|c|}
\hline & \multicolumn{2}{|r|}{ RVSP } & \multirow[t]{3}{*}{ Test value } & \multirow[t]{3}{*}{ P-value } & \multirow[t]{3}{*}{ Sig. } \\
\hline & & \multirow{2}{*}{$\begin{array}{c}\text { Group I Mild } \\
\text { No. }=36\end{array}$} & \multirow{2}{*}{$\begin{array}{c}\text { Group II Moderate to severe } \\
\text { No. }=4\end{array}$} & & & \\
\hline & & & & & & \\
\hline Age & $\begin{array}{l}\text { Mean } \pm \text { SD } \\
\text { Range }\end{array}$ & $\begin{array}{l}53.33 \pm 8.72 \\
36-69 \text { years }\end{array}$ & $\begin{array}{c}64.25 \pm 7.09 \\
54-69 \text { years }\end{array}$ & $-2.408 \bullet$ & 0.021 & $S$ \\
\hline \multirow[t]{2}{*}{ Sex } & Female & $20(55.6 \%)$ & $2(50.0 \%)$ & \multirow[t]{2}{*}{$0.045^{*}$} & \multirow[t]{2}{*}{0.832} & \multirow[t]{2}{*}{$\mathrm{NS}$} \\
\hline & Male & $16(44.4 \%)$ & $2(50.0 \%)$ & & & \\
\hline \multirow[t]{2}{*}{ DM } & No & $19(52.8 \%)$ & $0(0.0 \%)$ & \multirow[t]{2}{*}{$4.021 *$} & \multirow[t]{2}{*}{0.045} & \multirow[t]{2}{*}{$S$} \\
\hline & Yes & $17(47.2 \%)$ & $4(100.0 \%)$ & & & \\
\hline \multirow[t]{2}{*}{ HTN } & No & $18(50.0 \%)$ & $0(0.0 \%)$ & \multirow[t]{2}{*}{$3.636^{*}$} & \multirow[t]{2}{*}{0.057} & \multirow[t]{2}{*}{ NS } \\
\hline & Yes & $18(50.0 \%)$ & $4(100.0 \%)$ & & & \\
\hline
\end{tabular}


Table (8): Comparison between the degree of pulmonary hypertension and ECG repolarization parameters in group A

\begin{tabular}{|c|c|c|c|c|c|c|}
\hline & \multicolumn{2}{|c|}{ RVSP } & \multirow[t]{3}{*}{ Test value } & \multirow[t]{3}{*}{ P-value } & \multirow[t]{3}{*}{ Sig. } \\
\hline & & $\begin{array}{l}\text { Group I } \\
\text { Mild }\end{array}$ & $\begin{array}{c}\text { Group II } \\
\text { Moderate to severe }\end{array}$ & & & \\
\hline & & No. $=36$ & No. $=4$ & & & \\
\hline \multirow[t]{2}{*}{ QT max } & Mean \pm SD & $421.53 \pm 32.81$ & $450.75 \pm 40.43$ & \multirow[t]{2}{*}{$-1.657 \bullet$} & \multirow[t]{2}{*}{0.106} & \multirow[t]{2}{*}{ NS } \\
\hline & Range & $345-490 \mathrm{M} \mathrm{Sec}$ & $402-501 \mathrm{M} \mathrm{Sec}$ & & & \\
\hline \multirow[t]{2}{*}{ QT min } & Mean \pm SD & $395.72 \pm 39.43$ & $429.50 \pm 32.14$ & \multirow[t]{2}{*}{$-1.647 \bullet$} & \multirow[t]{2}{*}{0.108} & \multirow[t]{2}{*}{ NS } \\
\hline & Range & $306-485 \mathrm{M} \mathrm{Sec}$ & $402-476 \mathrm{M} \mathrm{Sec}$ & & & \\
\hline \multirow[t]{2}{*}{ QT dispersion } & Mean \pm SD & $34.41 \pm 14.76$ & $28.33 \pm 2.89$ & \multirow[t]{2}{*}{$0.701 \bullet$} & \multirow[t]{2}{*}{0.489} & \multirow[t]{2}{*}{ NS } \\
\hline & Range & $10-68 \mathrm{M} \mathrm{Sec}$ & $25-30 \mathrm{M} \mathrm{Sec}$ & & & \\
\hline \multirow{2}{*}{$\begin{array}{l}\mathrm{T} \text { wave alternans } \\
\text { amplitude }\end{array}$} & Absent & $30(83.3 \%)$ & $3(75.0 \%)$ & \multirow[t]{2}{*}{$0.173^{*}$} & \multirow[t]{2}{*}{0.677} & \multirow[t]{2}{*}{ NS } \\
\hline & Present & $6(16.7 \%)$ & $1(25.0 \%)$ & & & \\
\hline \multirow{2}{*}{$\begin{array}{l}\text { T wave alternans } \\
\text { morphology }\end{array}$} & Absent & $34(94.4 \%)$ & $4(100.0 \%)$ & \multirow[t]{2}{*}{$0.234 *$} & \multirow[t]{2}{*}{0.629} & \multirow[t]{2}{*}{ NS } \\
\hline & Present & $2(5.6 \%)$ & $0(0.0 \%) \mathrm{sec}$ & & & \\
\hline \multirow[t]{2}{*}{ QRS altenans } & Absent & $6(16.7 \%)$ & $1(25.0 \%)$ & \multirow[t]{2}{*}{$0.173 *$} & \multirow[t]{2}{*}{0.677} & \multirow[t]{2}{*}{ NS } \\
\hline & Present & $30(83.3 \%)$ & $3(75.0 \%)$ & & & \\
\hline
\end{tabular}

Table (9): The relation between risk factors and demographic data with degree of pulmonary hypertension in group A

\begin{tabular}{|c|c|c|c|c|c|c|}
\hline & \multicolumn{2}{|c|}{ RVSP } & \multirow[t]{3}{*}{ Test value } & \multirow[t]{3}{*}{ P-value } & \multirow[t]{3}{*}{ Sig. } \\
\hline & & $\begin{array}{l}\text { Group I } \\
\text { Mild }\end{array}$ & $\begin{array}{c}\text { Group II Moderate to } \\
\text { severe }\end{array}$ & & & \\
\hline & & No. $=36$ & No. $=4$ & & & \\
\hline Age & $\begin{array}{l}\text { Mean } \pm \text { SD } \\
\text { Range }\end{array}$ & $\begin{array}{l}53.33 \pm 8.72 \\
36-69 \text { years }\end{array}$ & $\begin{array}{l}64.25 \pm 7.09 \\
54-69 \text { years }\end{array}$ & $-2.408 \bullet$ & 0.021 & $\mathrm{~S}$ \\
\hline Sex & Female & $20(55.6 \%)$ & $2(50.0 \%)$ & $0.045 *$ & 0.832 & NS \\
\hline & Male & $16(44.4 \%)$ & $2(50.0 \%)$ & & & \\
\hline DM & No & $19(52.8 \%)$ & $0(0.0 \%)$ & $4.021 *$ & 0.045 & $\mathrm{~S}$ \\
\hline & Yes & $17(47.2 \%)$ & $4(100.0 \%)$ & & & \\
\hline HTN & No & $18(50.0 \%)$ & $0(0.0 \%)$ & $3.636^{*}$ & 0.057 & NS \\
\hline & Yes & $18(50.0 \%)$ & $4(100.0 \%)$ & & & \\
\hline
\end{tabular}

Table (10): The relation between the severity of pulmonary hypertension with ejection fraction, LV dilatation and diastolic function in group A

\begin{tabular}{|c|c|c|c|c|c|c|}
\hline & \multicolumn{2}{|c|}{ RVSP } & \multirow[t]{3}{*}{ Test value } & \multirow[t]{3}{*}{ P-value } & \multirow[t]{3}{*}{ Sig. } \\
\hline & & $\begin{array}{l}\text { Group I } \\
\text { Mild }\end{array}$ & $\begin{array}{c}\text { Group II Moderate } \\
\text { to severe }\end{array}$ & & & \\
\hline & & No. $=36$ & No. $=4$ & & & \\
\hline \multirow[t]{2}{*}{$\mathrm{EF}(\%)$} & Mean \pm SD & $56.64 \pm 11.16$ & $65.75 \pm 6.18$ & \multirow[t]{2}{*}{$-1.593 \bullet$} & \multirow[t]{2}{*}{0.120} & \multirow[t]{2}{*}{ NS } \\
\hline & Range & $38-79 \%$ & $62-75 \%$ & & & \\
\hline \multirow[t]{2}{*}{ Dimensions } & Normal & $24(66.7 \%)$ & $4(100.0 \%)$ & \multirow[t]{2}{*}{$1.905^{*}$} & \multirow[t]{2}{*}{0.168} & \multirow[t]{2}{*}{ NS } \\
\hline & Dilated LV & $12(33.3 \%)$ & $0(0.0 \%)$ & & & \\
\hline \multirow[t]{4}{*}{ Diastolic function } & Normal & $19(52.8 \%)$ & $1(25.0 \%)$ & \multirow[t]{4}{*}{$2.778^{*}$} & \multirow[t]{4}{*}{0.596} & \multirow[t]{4}{*}{ NS } \\
\hline & GI DD & $12(33.3 \%)$ & $3(75.0 \%)$ & & & \\
\hline & GII DD & $3(8.3 \%)$ & $0(0.0 \%)$ & & & \\
\hline & GIII DD & $1(2.8 \%)$ & $0(0.0 \%)$ & & & \\
\hline
\end{tabular}


Table (11): Relation between degree of pulmonary hypertension and valvular diseases, fractional shortening, RV size and function in group A

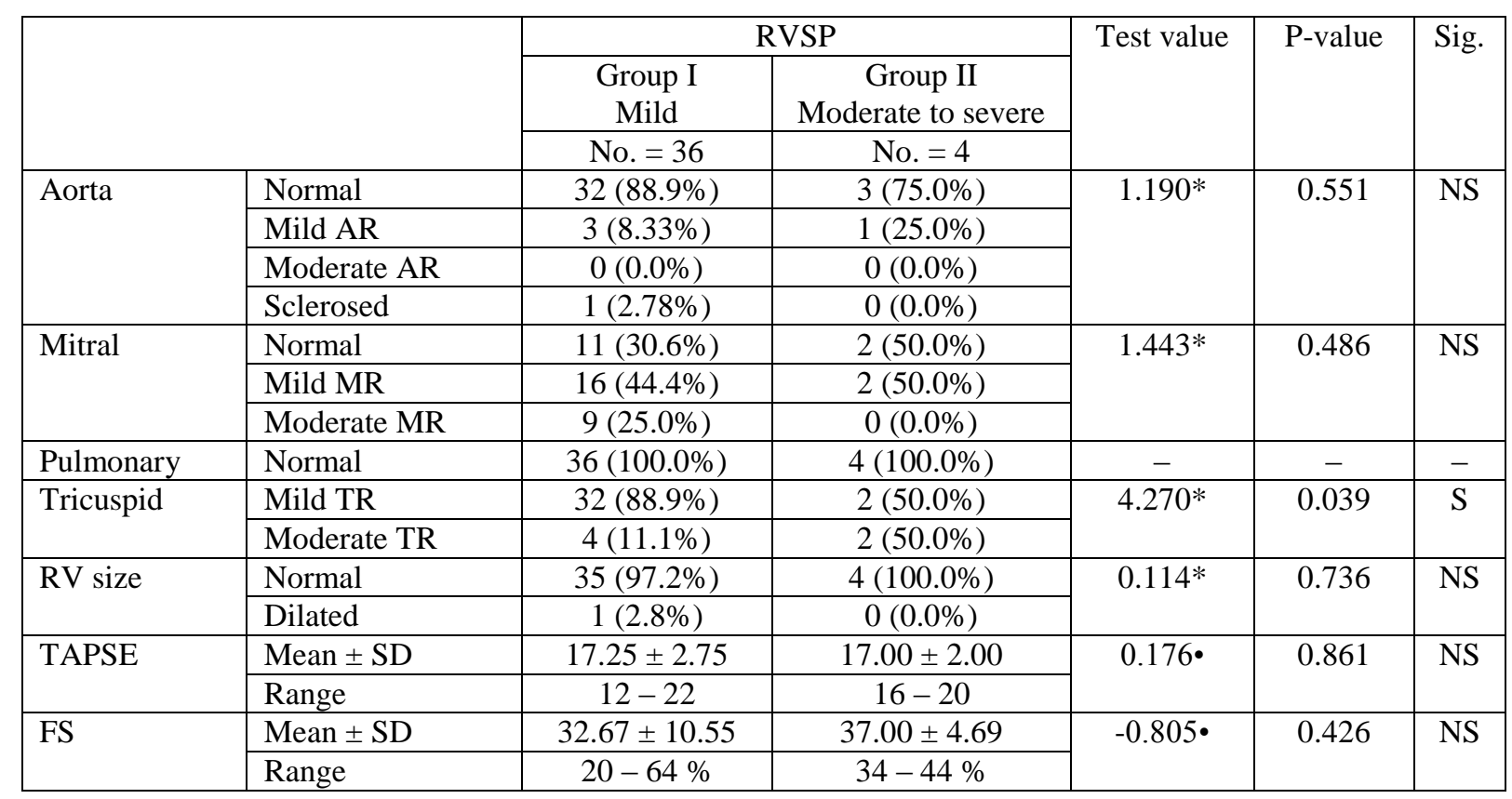

Table (12): Univariate logistic regression analysis for moderate to severe RVSP cases.

\begin{tabular}{|l|c|c|c|c|c|c|c|}
\hline & B & S.E. & Wald & P-value & Odds ratio & \multicolumn{2}{|c|}{ 95\% C.I. for OR } \\
\cline { 6 - 8 } & & & & & Low $)$ & Lower & Upper \\
\hline Age > 63 years & 3.497 & 1.303 & 7.204 & 0.007 & 33.000 & 2.568 & 423.990 \\
\hline Tricuspid regurge & 2.079 & 1.132 & 3.375 & 0.066 & 8.000 & 0.870 & 73.550 \\
\hline
\end{tabular}

\section{DISCUSSION:}

Our study included 80 patients presented to our outpatient clinic in Ain Shams University hospital and Nasser Institute Hospital. Patients were subjected to full history taking, examination, ECG and complete transthoracic Echocardiography. Patients were subdivided into two groups according to their pulmonary artery pressure measured by echocardiography.

\section{- Group (A):}

Patients have PASP above $35 \mathrm{mmHg}$.

\section{- Group (B):} $\mathrm{mmHg}$.

Patients have PASP less than 35

In the present study, the age ranged between 37 and 67 years with mean age of
$54.43 \pm 9.11$ for group A and a mean age of $50.55 \pm 7.91$ for group B. In addition, $46 \%$ of the studied groups were males resembling (37 out of 80).

Our study showed that the mean age was higher in patients with severe pulmonary hypertension. Furthermore, elderly was a strong predictor of pulmonary hypertension.

The results of this study were concordant with Schachna et al. who studied the association of age with occurrence of pulmonary hypertension in 900 patients in USA. They showed that the incidence of PAH increased linear with age ${ }^{(12) .}$

In the present study, the prevelance of diabetes was $52.5 \%$ in pulmonary hypertension group and $37.5 \%$ in the control 
group. Moreover, the prevelance of diabetes was much higher in patients with severe pulmonary hypertension.

These results were concordant with Pugh et al. study who defined the prevalence of elevated $\mathrm{HbA1c}$ in PAH patients. In his study, HbA1c was measured in $41 \mathrm{PAH}$ patients without a diagnosis of DM, along with demographic, functional, and hemodynamic data. The results showed $71 \%$ of the studied patients had $\mathrm{HbAlc} \geq 6.0 \%{ }^{(13)}$.

Our study showed that there was no significant difference in mean QTc and QTcd between patients with pulmonary hypertension and the control group.

On the other hand, Hong-liang $\mathrm{Z}$ et al., examined QTc and QTcd in pulmonary hypertension and assessed their relationship with pulmonary arterial pressure.

Hong-liang $\mathrm{Z}$ study included a total of 201 patients diagnosed with PHT. The study has found that in all observed cases, mean QTc was higher in severe pulmonary hypertension than in controls and QTcd was higher in patients with pulmonary hypertension than in controls ${ }^{(14)}$.

The difference between our study and Hong-liang study may be attributed to the difference in the number of cases as our study included 40 patients with pulmonary hypertension while Hong-liang $\mathrm{Z}$ study included 201 patients with pulmonary hypertension. In addition, Hong-liang Z study measured pulmonary artery pressure with right heart catheterization while our study measured pulmonary artery pressure with transthoracic echocardiography.

Our study showed that there is no significant correlation between $\mathrm{T}$ wave alternans in amplitude or width with pulmonary hypertension.

To our knowledge, this study is the first to investigate the relation between $\mathrm{T}$ wave alternans and pulmonary hypertension while multiple trials have studied the relation between micro voltage $\mathrm{T}$ wave alternans and pulmonary hypertension.

Ludmiła Daniłowicz-Szymanowicz has studied the profile of micro voltage $\mathrm{T}$ wave (MTW) alternans among PAH patients in comparison with LVD patients and healthy volunteers. The study included 22 patients with PAH (mean age, $40 \pm 17$ years); 24 with LVD [left ventricular ejection fraction $(\mathrm{LVEF}) \leq 35 \%$; mean age, $40 \pm 11$ years]; and 28 healthy volunteers (mean age, $41 \pm 8$ years). MTW abnormality was observed more frequently in the PAH and LVD groups than in the healthy volunteers ${ }^{(15)}$.

QRS alternans is not massively studied and our study is the first to investigate the relation between QRS alternans and pulmonary hypertension. Our results showed that there was no significant relation between QRS alternans and pulmonary hypertension. In addition, there was no significant relation between incidence of QRS alternans and the severity of PAH.

Our study showed that reduced ejection fraction is common among patients with pulmonary hypertension. In addition, the multi-varialte logistic regression analysis for predictors of pulmonary hypertension found that the reduction of the ejection fraction is the strongest predictor of pulmonary hypertension.

Our study goes with Stephan Rosen Kranz study who studied the prevalence and significance of $\mathrm{PH}$ and $\mathrm{RV}$ dysfunction in patients with $\mathrm{HF}$ with reduced ejection fraction (HFrEF), it was found that Pulmonary hypertension related to left heart disease (LHD) by far represents the most common form of $\mathrm{PH}$, accounting for $65-80 \%$ of cases ${ }^{(16)}$.

In addition, our results go with Srinath and Jeremy In their cohort of 1174 patients with unexplained cardiomyopathy. Srinath found that $40 \%$ of patients had a mean pulmonary artery pressure $\geq 25 \mathrm{mmHg}$ consistent with PH-LHD ${ }^{(17)}$. 
Regarding the diastolic function, our study showed that there is no significant relation between pulmonary hypertension and incidence of diastolic dysfunction.

Our results do not go with Moustapha et al who evaluated the left ventricular diastolic function by echocardiography in patients with chronic pulmonary hypertension. The study included 120 patients with PAH (57 with severe and 63 with mild or moderate $\mathrm{PAH}$ ) and compared them with 75 normal controls. Systolic pulmonary artery pressure (SPAP) was measured by tricuspid regurgitant jet method and the usual transmitral LV diastolic indices were recorded ${ }^{(18)}$.

They found that LV diastolic dysfunction was most commonly seen in patients with severe PAH and no differences were observed between patients with mild and moderate PAH. A SPAP $\geqq 60 \mathrm{~mm} \mathrm{Hg}$ is needed to induce changes in the LV diastolic function.

The present study was different from Mustapha et al. study in the total number of cases. Additionally, our study included 3 patients with severe pulmonary hypertension while Moustapha et al. study involved 57 patients with severe pulmonary hypertension

In the present study, the results showed that $45 \%$ of patients with pulmonary hypertension had mild mitral regurgitation while $22.5 \%$ had moderate mitral regurgitation. In addition, our results did not find relation between the degree of mitral regurge and the severity of pulmonary hypertension.

Our results go with Enriquez-Sarano et al in their study on determinants of pulmonary hypertension in patients with left ventricular dysfunction. The study involved 102 consecutive patients with primary left ventricular dysfunction (ejection fraction $<50 \%$ ), systolic pulmonary artery pressure was prospectively measured by Doppler echocardiography (using tricuspid regurgitant velocity), and left ventricular systolic and diastolic function, functional mitral regurgitation, cardiac output and left atrial volume were quantified ${ }^{(19)}$.

Systolic pulmonary artery pressure was found to be elevated in patients with left ventricular dysfunction. Of the numerous variables correlating significantly with systolic pulmonary artery pressure, the strongest were mitral deceleration time and mitral effective regurgitant orifice. In multivariate analysis, these two variables were the strongest predictors of systolic pulmonary artery pressure in association with age ${ }^{(19)}$.

In the present study, $85 \%$ of our patients with pulmonary hypertension had mild tricuspid regurgitation while $15 \%$ had moderate tricuspid regurgitation. Moreover, $50 \%$ of patients with severe pulmonary hypertension had moderate tricuspid regurgitation. Therefore, there was significant relation between the degree of tricuspid regurgitation and the severity of pulmonary hypertension.

Our results go with Mutlak et al. who made a randomized trial on Functional Tricuspid Regurgitation in Patients with Pulmonary Hypertension. The study included 2,139 patients with pulmonary hypertension. Echocardiographic reports and selected echocardiographic studies of patients with echocardiographic estimation of PASP were reviewed. Patients with organic tricuspid valve (TV) disease were excluded from the analysis ${ }^{(20)}$.

From their study, it was found that PASP is a strong determinant of TR severity, but many patients with pulmonary hypertension do not exhibit significant TR. Furthermore, the frequency of moderate or severe TR was progressively greater in patients with higher PASP. Nevertheless, TR was only mild in a substantial proportion of patients with high PASP (mild TR in $65.4 \%$ 
of patients with PASP $50-69 \mathrm{~mm} \mathrm{Hg}$ and in $45.6 \%$ of patients with $\mathrm{PASP} \geq 70 \mathrm{~mm}$ $\mathrm{Hg})^{(20)}$.

The present study differs from Mutlak et al. trial in the total number of patients. In addition, the number of patients with severe pulmonary hypertension is relatively higher in Mutlak et al trial.

The present study showed that there was no significant relation between pulmonary hypertension and right ventricular size and function in which only $4 \%$ of patients had dilated right ventricle.

Our results goes with the data from A López-Candales et al. who studied right ventricular (RV) fractional area change and tricuspid annular plane systolic excursion (TAPSE) as a recognized methods for assessing RV function in 190 patients with variable degrees of pulmonary hypertension. The study results provided a range of normal variables of RV size and function in patients with pulmonary hypertension ${ }^{(21)}$.

Our results were discordant with Lai et al. who studied the Pathophysiology of Impaired Right and Left Ventricular Function in chronic Pulmonary Hypertension. The study involved 39 patients (16 women and 23 men; mean \pm SD age, $55 \pm 12$ years) with severe pulmonary hypertension. The results showed that functions are impaired in the right as well as the left ventricles of the heart in those patients with severe pulmonary hypertension (22).

\section{Conclusion:}

In the present study we found that there is no significant relation between $\mathrm{T}$ wave alternans, $\mathrm{R}$ wave alternans and QT dispersion. In addition, there is no significant relation between the degree of pulmonary hypertension and the incidence of QT dispersion, T wave alternans and QRS alternans.

\section{Study Limitations}

The results were obtained from only two medical centers, with a rather small sample size (80 patients). Small sample size Right heart catheterization was not done.

\section{REFERENCES:}

1. Rubin MT, (2016): Primary pulmonary hypertension. Geneva: World Health Organization Cell Tissue Res. 2017 Mar; 367(3): 643-649.

2. McLaughlin VV, Archer SL, Badesch DB, et al. "ACCF/AHA 2009: Expert consensus document on pulmonary hypertension a report of the American College of Cardiology Foundation Task Force on Expert Consensus Documents and the American Heart Association developed in collaboration with the American College of Chest Physicians; American Thoracic Society, Inc.; and the Pulmonary Hypertension Association". Journal of the American College of Cardiology 2009; 119(16):2250-94.

3. Galie N, Hoeper MM, Humbert M, et al. 2009: Guidelines for the diagnosis and treatment of pulmonary hypertension: the Task Force for the Diagnosis and Treatment of Pulmonary Hypertension of the European Society of Cardiology (ESC) and the European Respiratory Society (ERS), endorsed by the International Society of Heart and Lung Transplantation (ISHLT). European heart journal 2009; 30(20):2493537.

4. Batal O, Khatib OF, Dweik RA, et al.2012: Comparison of baseline predictors of prognosis in pulmonary arterial hypertension in patients surviving $\leq 2$ years and those surviving $\geq 5$ years after baseline right- sided cardiac catheterization. Am J Cardiol 2012; 109(10):1514-20.

5. Demerouti EA, Manginas AN, Athanassopoulos GD, et al. 2013: Complications Leading to sudden cardiac death in pulmonary arterial hypertension. Respir Care 2013; 58: 1246-54. 
6. Perkiömaki JS, Koistinen MJ, Yli-Mayry S, et al. 1995: Dispersion of QT interval in patients with and without susceptibility to ventricular tachyarrhythmias after previous myocardial infarction. Journal of the American College of Cardiology 1995; 26(1):174-9.

7. Bazett HC. (1920). "An analysis of the time-relations of electrocardiograms". Heart (7): 353-370

8. Saghir S, Bartone C, Goebel M, et al.2007: "Usefulness of microvolt $\mathrm{T}$-wave alternans on predicting outcome in patients with ischemic cardiomyopathy with and without defibrillators". Am J Cardiol (August 2007). 100 (4): 598-604.

9. Antonio Bayés de Luna (2011). Clinical Arrhythmology. John Wiley and Sons. p. 351.

10. Pamela S. Douglas, Mario J. Garcia, David E.Haines, et al. 2011: Appropriate Use Criteria for echocardiography, J Am Soc Echocardiogr 2011; 24:229-67.

11. Lawrence G. Rudski, Wyman W. Lai, Jonathan Afilalo, et al., 2010: Guidelines for the Echocardiographic Assessment of the Right Heart in Adults: A Report from the American Society of Echocardiography, J Am Soc Echocardiogr 2010;23:685-71.

12. Schachna L, Wigley FM, Chang B, et al. 2003: Age and risk of pulmonary arterial hypertension in scleroderma. Chest 2003; 124(6):2098-104.

13. Pugh ME, Robbins IM, Rice TW, et al. 2011: Unrecognized glucose intolerance is common in pulmonary arterial hypertension. The Journal of heart and lung transplantation 2011; 30(8):904-11.

14. Hong-liang Z, Qin L, Zhi-hong L, et al. 2009: Heart rate-corrected QT interval and QT dispersion in patients with pulmonary hypertension. Wiener Klinische Wochenschrift 2009; 121(9-10):330-3.
15. Daniłowicz-Szymanowicz L, Lewicka E, Dąbrowska-Kugacka A, et al. 2016: Microvolt T-wave alternans profiles in patients with pulmonary arterial hypertension compared to patients with left ventricular systolic dysfunction and a group of healthy volunteers. Anatolian journal of cardiology 2016; 16(11):825.

16. Stephan Rosenkranz J, Simon R Gibbs, Rolf Wachter, et al. 2015: Left Ventricular Heart Failure and Pulmonary Hypertension, European Heart Journal.Swan-Ganz - right heart catheterization: MedlinePlus Medical Encyclopedia 2015; 17(1):74-80.

17. Srinath A and Jeremy AM. Pulmonary Hypertension Due to Left Ventricular Cardiomyopathy 2017: Is it the Result or Cause of Disease Progression? Curr Heart Fail Rep 2017; 14(6): 507-513.

18. Moustapha A, Kaushik V, Diaz S, et al. 2001: Echocardiographic evaluation of leftventricular diastolic function in patients with chronic pulmonary hypertension. Cardiology 2001; 95(2):96-100.

19. Enriquez-Sarano M, Rossi A, James B, et al. 1997: Determinants of Pulmonary Hypertension in Left Ventricular Dysfunction. Journal of the American College of Cardiology 1997; 29(1) 153-159

20. Mutlak D, Aronson D, Lessick J, et al. 2009: Functional tricuspid regurgitation in patients with pulmonary hypertension: is pulmonary artery pressure the only determinant of regurgitation severity? Chest 2009; 135(1):115-21.

21. Lopez-Candales A, Dohi K, Rajagopalan N, et al. 2008: Defining normal variables of right ventricular size and function in pulmonary hypertension: an echocardiographic study. Postgraduate medical journal 2008; 84(987):40-5.

22. Lai YC, Potoka KC, Champion HC, et al. 200: Pulmonary arterial hypertension: the clinical syndrome. Circulation research 2014; 115(1):115-30. 
العلاقة بين ارتفاع ضغط الثريان الرئوى والذى يقاس بالموجات الصوتية على القلب وتناوب الجها الكهربى فى رئ

$$
\text { موجتى في رسم القلب الكهرئ بالموجى (T,R) }
$$

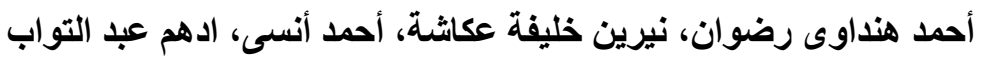

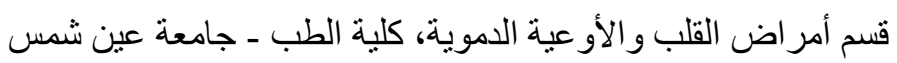

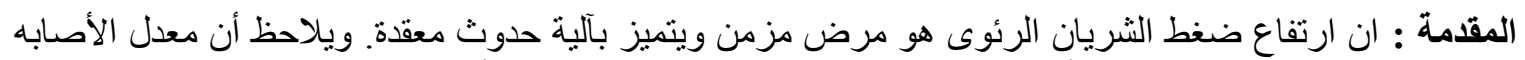

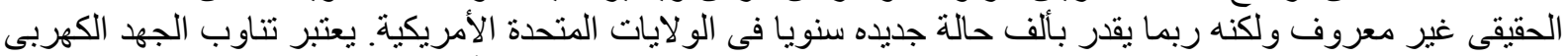

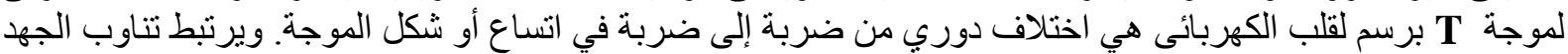

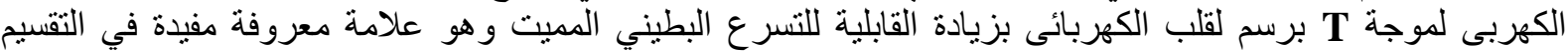
الطبقي لخطر عدم انتظام ضربات القلب البطيني المهدد للحياة والموت القيات القبي المفاجئ.

الهدف من العمل: العلاقة بين ارتفاع ضغط الثريان الرئوى و الذى يقاس بالموجات الصوتية على القلب وتناوب الجها

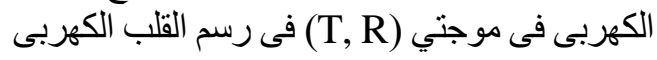

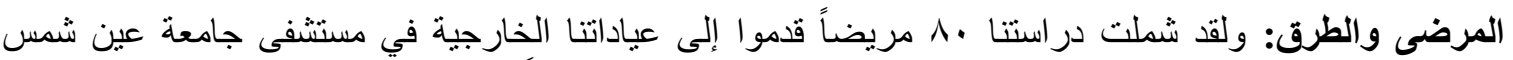

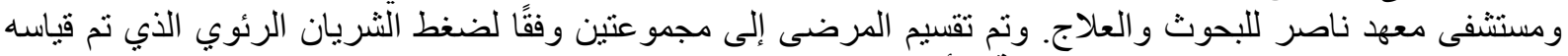

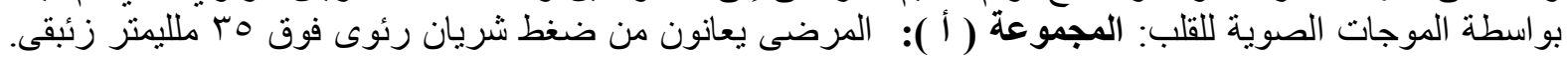

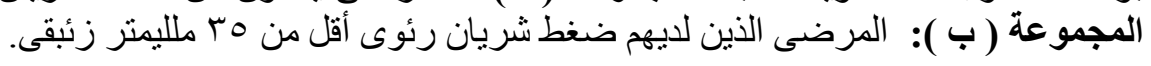

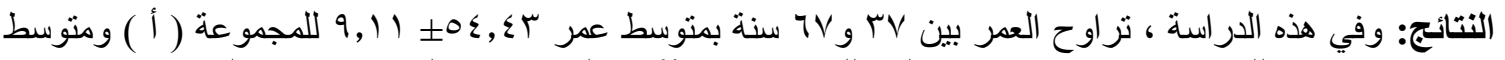

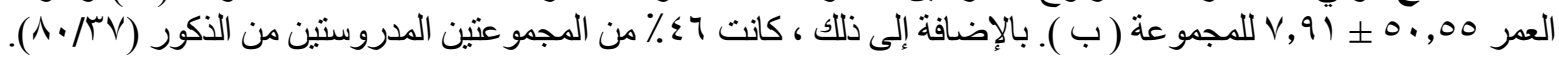

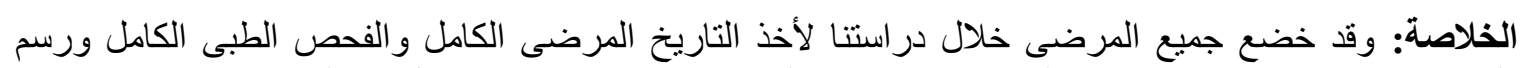

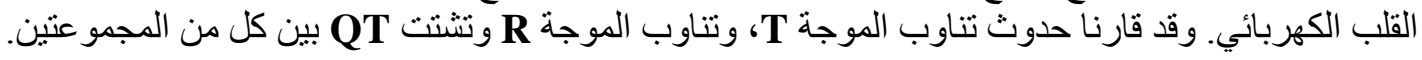

